\title{
BADANIA KORELACJI PIERWIASTKÓW ŚLADOWYCH W ŚRODOWISKU GLEBOWO - ROŚLINNYM PRZY ZASTOSOWANIU METOD GIS
}

\begin{abstract}
Celem prezentowanego opracowania jest identyfikacja anomalnych koncentracji geochemicznych $\mathrm{w}$ glebach oraz korzeniu marchwi pochodzących $\mathrm{z}$ ogródków działkowych miasta Przemyśla. Przy zastosowaniu technik kartograficznych wykonano mapy monitoringu środowiska zanieczyszczeń, obejmujących rejestracje miejsc zakładów przemysłowych, wprowadzających wyznaczone pierwiastki śladowe do środowiska przyrodniczego. Technologie te umożliwiły również wizualizację interakcji zachodzących między systemem przyrodniczym typu gleba-roślina i wykonaniu map korelacji występującej w tym układzie. W ramach badań chemicznych, przy zastosowaniu atomowej spektroskopii absorpcyjnej (ASA), wyznaczono koncentrację kadmu, ołowiu i miedzi w roślinach oraz glebach. Badania mineralogiczne przy zastosowaniu dyfraktometrii rentgenowskiej oraz mikroskopii skenningowej, umożliwiły określenie składu fazowego badanych gleb. Wszystkie operacje i czynności związane z analizą przestrzenną i kartowaniem wykonane zostały w opensource owym systemie QGIS/GRASS. Uzyskane wyniki badań chemicznych dla materiału roślinnego oraz gleb pozwalają stwierdzić, że we wszystkich 14 miejscach pomiarowych została przekroczona górna dopuszczalna granica zawartości Cd podawana w rozporządzeniu 420/211 komisji UE z 2011 roku. Zawartość $\mathrm{Cu}$ i $\mathrm{Pb}$ we wszystkich próbkach nie przekraczają dopuszczalnych norm. Mapy korelacji pomiędzy środowiskiem glebowym a roślinnym potwierdzają wyniki badań geochemicznych. Miejsca największej koncentracji kadmu pokrywają się $\mathrm{z}$ podwyższoną zawartością tego pierwiastka w roślinach.
\end{abstract}

Słowa kluczowe: kartografia, geochemia, monitoring środowiska, pierwiastki śladowe, kadm, interpolacja, QGIS/GRASS

\section{Wprowadzenie}

W monitoringu środowiska naturalnego szczególne miejsce zajmują gleby oraz roślinność je porastająca. Stanowią one abiotyczne elementy ekosystemów

\footnotetext{
${ }^{1}$ Autor do korespondencji/corresponding autor: Agnieszka Pękala, Politechnika Rzeszowska, Wydział Budownictwa, Inżynierii Środowiska i Architektury, ul. Poznańska 2, 35-084 Rzeszów, apekala@prz.edu.pl

${ }^{2}$ Ewa Głowienka, Politechnika Świętokrzyska, Wydział Inżynierii Środowiska, Geomatyki i Energetyki, Al. Tysiąclecia Państwa Polskiego 7, 25-314 Kielce, eglo@interia.pl
} 
o znaczącej roli w obiegu pierwiastków w przyrodzie. Środowisko glebowo roślinne jest strefą szczególnie narażoną na zanieczyszczenia metalami ciężkimi, pochodzącymi z emisji pyłów przemysłowych, komunikacyjnych, zanieczyszczeń z gospodarki komunalnej czy rolnictwa. Przemieszczanie się tych związków z gleby do organizmów zwierząt i ludzi zachodzi przede wszystkim poprzez rośliny, które są najważniejszym ogniwem w łańcuchu troficznym: gleba-roślina - zwierzę - człowiek.

W ramach badań środowiska gruntowo - roślinnego na zawartość w nim pierwiastków śladowych wykonano analizy geochemiczno - mineralogiczne. Pomocnymi metodami w interpretacji uzyskanych wyników oraz przy korelacji zawartości pierwiastków śladowych w układzie gleba - roślina, są metody geodezyjne głównie, techniki kartograficzne oraz technologie GIS i teledetekcji. Wymienione techniki są wykorzystywane w kilku dziedzinach geologii $[1,2,3]$ obejmujących: kartowanie geologiczne, poszukiwanie złóż rud metali, kaustobiolitów i źródeł geotermalnych. Zastosowanie metod GIS z geochemicznego punktu widzenia jest szczególnie istotne przy monitoringu zanieczyszczeń, zwłaszcza biorąc pod uwagę zmiany zachodzące na określonej przestrzeni czasowej.

Anomalie geochemiczne $\mathrm{w}$ glebach prowadzą do zwiększenia zawartości pierwiastków toksycznych w roślinach, Kartowanie stężenia obu typów zanieczyszczeń wymaga pozyskanie odpowiednich próbek w terenie. Ich liczba zależy od szczegółowości prowadzonych badań, tj. od skali map, na których mają być przedstawione wyniki (Pasieczna, 2004). Mapy geochemiczne opracowywane są w różnych skalach w zależności od ich przeznaczenia. Mogą to być mapy przeglądowe (1: $500000 \div 1: 5000$ 000), regionalne $(1: 100000 \div 1: 300000)$ lub szczegółowe (1: $10000 \div 1: 25$ 000). Wyniki dotychczasowych badań geochemicznych zostały opublikowane przez Państwowy Instytut Geologiczny w latach 1991-2003 w formie atlasów geochemicznych. Ponadto, w roku 2015 PIG udostępnił 17 map geochemicznych w formie usług sieciowych WMS (Web map serice) (PIG, 2015). Udostępnione mapy geochemiczne przedstawiają zawartości pierwiastków w odniesieniu do wydzielenia geologicznego (PIG, 2015)[4].

\subsection{Charakterystyka badanego obszaru}

Przemyśl to historyczne miasto położone w południowo - wschodniej Polsce nad rzeką San. Zajmuje powierzchnię około $44 \mathrm{~km}^{2}$ i należy do wschodniej części województwa podkarpackiego. Zlokalizowany jest w odległości około $78 \mathrm{~km}$ na południowy wschód do Rzeszowa i $12 \mathrm{~km}$ na zachód od granicy państwowej z Ukrainą. Z racji licznych walorów przyrodniczych oraz wielu zabytków stanowi rejon coraz częściej odwiedzany przez turystów. Jednym z podstawowych zasobów naturalnych analizowanego terenu są gleby. Dolina Sanu od Przemyśla do ujścia Wisłoka rozdziela obszar województwa podkarpackiego na część północno - wschodnią z glebami brunatnymi i pyłowymi z dużym udziałem gleb bielicowych oraz na część południowo zachodnią, w której występują 
gleby brunatne i czarnoziemy, wytworzone na podłożu lessowym. Mady doliny Sanu, gleby pyłowe lekkie i średnie zaliczane są do najlepszych gleb w powiecie, to jest kompleksu pszennego I i II klasy bonitacyjnej. Od północnej części Przemyśla poprzez Radymno za Jarosław ciągnie się szeroki pas gleb typu czarnoziemy, który w połączeniu z czarnoziemami łąkowymi, stanowi $11,8 \%$ gleb użytkowanych rolniczo. Na Pogórzu Przemyskim dominują gleby kompleksu zbożowy górski, na glebach brunatnych pyłowych i ilastych np.: w obszarze Wiaru. W Karpatach Brzeżnych części przemyskiej najczęściej występują gleby pyłowe powstałe ze zwietrzeliny fliszu.

$\mathrm{Na}$ omawianym terenie pierwotnym źródłem zanieczyszczenia środowiska jest emisja pyłów i dymów pochodzących ze spalania surowców energetycznych zawierających zanieczyszczenia, których udział jest zależny od rodzaju węgla i spalanych odpadów. Do ważnych źródeł zanieczyszczeń zlokalizowanych na terenie miasta zaliczyć należy drobne i średnie zakłady przemysłowe. Na terenie Przemyśla zlokalizowano cztery zakłady przemysłowe o najwyższej emisji zanieczyszczeń, w pobliżu których pobrano materiał do przeprowadzonych badań. Należą do nich:
A. MPEC Sp. z o.o. ( Ciepłownia „Zasanie”),
B. Zakład Wyrobów Powlekanych , Sanwil” S.A,
C. Zakład Automatyki „Polna” S.A,
D. Fibris S.A Zakład płyt Pilśniowych.

\subsection{Monitoring środowiska glebowo - roślinnego miasta Przemyśla}

Aktualny stan i ocena jakości środowiska na rok 2013 w Przemyślu zostały przedstawione w oparciu o opracowany przez WIOŚ w Rzeszowie dokument pt „Stan środowiska w województwie podkarpackim w latach 1999-2008. Dane w nim zawarte są zgodne $\mathrm{z}$ regulacjami prawnymi, wynikającymi z ustawy Prawo ochrony środowiska $z$ dnia 27 kwietnia 2001r. (Dz.U. Nr 62 poz. 627 z późn. zm.) i przepisami wykonawczymi oraz dostosowane do norm, wynikających z przepisów Unii Europejskiej. Dokument ten pt: „Program ochrony środowiska dla miasta Przemyśla na lata 2010 - 2013, z perspektywą do 2017 r”. nie obejmuje jednak monitoringu gleb miasta Przemyśla [5]. Ostanie dane odnośnie, badań gleb i roślin wokół zakładów przemysłowych Przemyśla podaje raport z 1994, Wojewódzkiego Inspektoratu Ochrony Środowiska w Przemyślu. Według danych PIOŚ w glebach pochodzących z ogródków działkowych zlokalizowanych wokół Ciepłowni „Zasanie” zarejestrowano w większości punktów pomiarowych podwyższoną koncentracje kadmu, przekraczającą górną granicę zawartości naturalnych. Zawartość kadmu w roślinach tego rejonu była znacznie niższa niż dolna granica zawartości toksycznej, nie mniej jednak niemal we wszystkich punktach przekraczała górną granicę zawartości spotykanych w klasie roślin jednoliściennych. Badania próbek glebowych pobranych wokół ZWP „Sanwil” wykazały, że zawartość kadmu, miedzi i cynku mieściła się w granicach zawartości naturalnej. 
Zawartości zaś ołowiu w wielu punktach przekroczyły górną granice zawartości naturalnych. Na podstawie uzyskanych danych, według wytycznych opracowanych przez IUNiG w Puławach w roku 1992 dokonano ekologicznej klasyfikacji gleb wokół powyższych zakładów Przemyśla. Gleby z rejonu Ciepłowni „Zasanie" zakwalifikowano do IV i III klasy zanieczyszczeń kadmem. Gleby pobrane w rejonie ZWP „Sanwil” były nieco mniej zanieczyszczone i na całym badanym terenie zostały zakwalifikowane do III klasy zanieczyszczeń ze względu na zawartość kadmu [6].

\section{Metodyka badań terenowych i laboratoryjnych}

Próbki do przeprowadzonych badań pobrano zgodnie z Polską normą (PNR-04031:1997) z południowo wschodniej części miasta oraz z obszarów nadzalewowych w pobliżu miejsc o znacznej emisji zanieczyszczeń. Łącznie analizom poddano 14 próbek gleb i 14 próbek roślin (korzeń marchwi). Miejsce pobrania próbek przedstawia Rys. 1. W pobranym materiale glebowym i roślinnym, przy zastosowaniu atomowej spektroskopii absorpcyjnej (ASA) na spektrometrze PHILIPS PU 9100Xi Camera SX-100, oznaczono koncentrację takich pierwiastków śladowych jak: ołów, kadm i miedź.

W celu dokładnej identyfikacji składu chemicznego cząstek występujących w glebach Przemyśla, przeprowadzono dodatkowe badania wykorzystujące metodę dyfrakcji rentgenowskiej (XRD) oraz elektronowej mikroskopii skaningowej wraz z metodą dyspersji energii promieniowania rentgenowskiego (EDX).

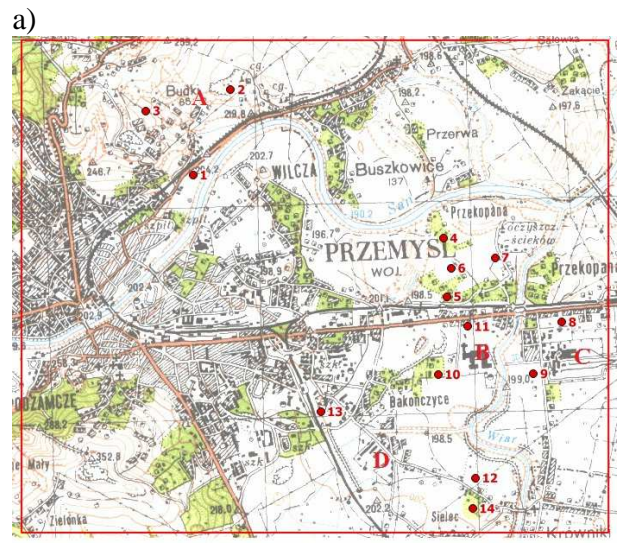

b)

Rys. 1. Lokalizacja poboru próbek na wybranym obszarze badań przygotowana na podkładzie: a) mapy topograficznej b) ortofotomapy (WMS geoportal.gov.pl, dostęp wrzesień 2015)

Fig. 1. Location of sampling points on the selected area of research prepared for base-map: a) a topographic map b) orthophoto map (WMS geoportal.gov.pl, access september 2015) 
W trakcie pomiaru terenowego lokalizacja każdego punktu poboru próbki gleby została zmierzona za pomocą odbiornika GPS. Wszystkie operacje i czynności związane $\mathrm{z}$ analizą przestrzenną i kartowaniem wykonane zostały w opensource'owym systemie QGIS/GRASS.

W oparciu o współrzędne punktów poboru próbek przygotowano numeryczną siatkę punktów pomiarowych, którą zapisano jako warstwa wektorowa w formacie ESRI Shape file. Na jej podstawie utworzony został obszar testowy o wymiarach $5,5 \mathrm{~km} \times 4,5 \mathrm{~km}$ podlegający dalszemu opracowaniu (Rys.1). W celu dokładnej analizy topograficznej i sytuacyjnej utworzona siatka punktów pomiarowych została nałożona na podkład mapy topograficznej (Rys.1a), ortofotomapy (Rys.1b) oraz numeryczny model terenu (pochodne: cieniowanie i mapa hipsometryczna) (Rys.2) dostępne jako usługi sieciowe WMS (Web Map Sernice). Na podstawie map wysokościowych zbadano ekspozycję poszczególnych punktów pomiarowych, co umożliwiło sprawdzenie potencjalnej migracji zanieczyszczeń, które mogło być spowodowane deniwelacją terenu.

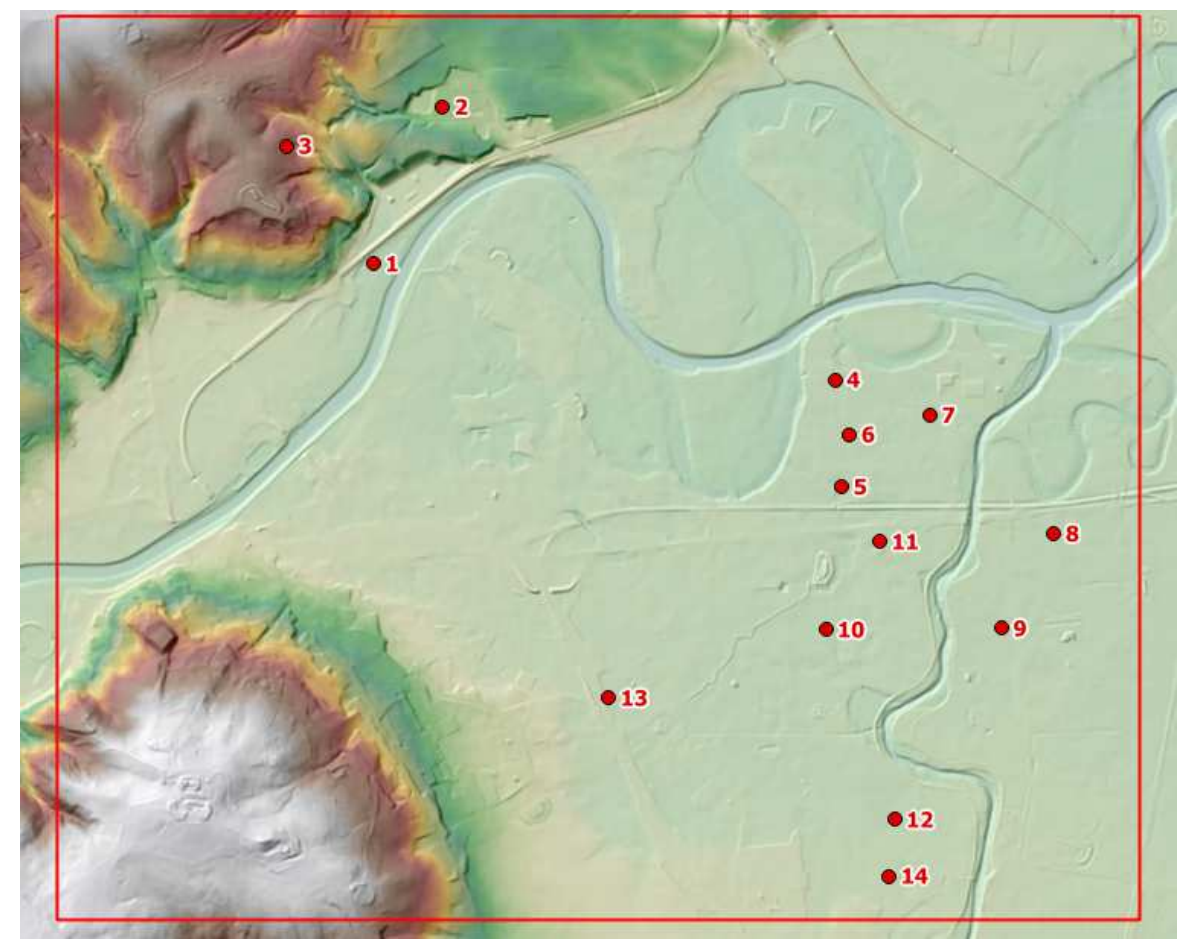

Rys.2. Rozmieszczenie punktów pomiarowych na wybranym obszarze badań na podkładzie danych wysokościowych (mapa hipsometryczna i mapa cieniowania) (WMS Geoportal.gov.pl, dostęp wrzesień 2015)

Fig.2. Arrangement of measurement points on a selected area of research on the base-map of elevation data (hypsometric map and the shading map) (WMS Geoportal.gov.pl, access september 2015) 
Następnie wykorzystując algorytm interpolacji RST (Regularized Spline with Tension), zaimplementowany w systemie GRASS, wykonano kompozycje mapowe stężeń poszczególnych pierwiastków oznaczonych w próbach glebowych (Rys.3, Rys.4, Rys.5) oraz korzeniach marchwi. Metoda RST używa funkcji interpolującej, która jest sumą funkcji trendu i zmienności lokalnej. W ten sposób uzyskano mapy rastrowe stanowiące dwuwymiarowy model stężenia oznaczanych pierwiastków na badanym terenie. Uzyskane mapy w sposób ciągły przedstawiały stężenie oznaczanych pierwiastków dla każdego punktu w obrębie siatki pomiarowej. W celu analizy korelacji stężeń badanych pierwiastków w glebie i w roślinach, przygotowane zostały dodatkowe wektorowe mapy izolinii, przedstawiające stężenia: $\mathrm{Pb}, \mathrm{Cd}, \mathrm{Cu}$ w korzeniach marchwi (Rys.3, Rys.4, Rys.5). Mapy te wygenerowano w oparciu o opracowane uprzednio rastrowe mapy stężeń analizowanych pierwiastków.

\section{Analiza i interpretacja wyników}

W badanych glebach i materiale roślinnym (korzeniu marchwi) oznaczono zawartość pierwiastków śladowych: $\mathrm{Pb}, \mathrm{Cd}, \mathrm{Cu}$. Ponadto dla gleb zostały wyznaczone wartości ich kwasowości oraz w oparciu o badania mineralogiczne ustalono ich skład fazowy. Biorąc pod uwagę wymagania zawarte w Rozporządzeniu Ministra Środowiska z dnia 9 września 2002 w sprawie standardów jakości gleby oraz standardów jakości ziemi [7] (tab. 1), można stwierdzić, iż zawartości pierwiastków śladowych $\mathrm{Pb}, \mathrm{Cu}$ uzyskane w wyniku analizy geochemicznej gleb i korzeni marchwi, nie przekraczają dopuszczalnych wartości Należy podkreślić, że z badanych pierwiastków, jedynie kadm charakteryzuje się wartością najbardziej zbliżoną do górnej granicy dopuszczalnej w glebach tj. zawartości 4 mg / kg s.m, określonej w Rozporządzeniu Ministra Środowiska. Największa zawartość kadmu w analizowanych próbkach wyniosła 2,6 ppm (próbka nr 11) (tab.1). Ponadto, warto zaznaczyć, że koncentracje te są również

Tabela 1. Wartości statystyczne stężeń $\mathrm{Pb}, \mathrm{Cd}$ i Cu w glebie i materiale roślinnym z terenu Przemyśla.

Table 1. Statistical values of concentrations of $\mathrm{Pb}, \mathrm{Cd}$ and $\mathrm{Cu}$ in soil and plant material from the Przemysl area.

\begin{tabular}{|l|c|c|c|c|c|c|}
\hline \multirow{2}{*}{$\begin{array}{c}\text { Wartość } \\
\text { statystyczna }\end{array}$} & \multicolumn{2}{|c|}{$\begin{array}{c}\text { Stężenie pierwiastków ślado- } \\
\text { wych w glebie [ppm s.m.] }\end{array}$} & \multicolumn{3}{c|}{$\begin{array}{c}\text { Stężenie pierwiastków ślado- } \\
\text { wych w roślinach } \\
\text { [ppm s.m] }\end{array}$} \\
\cline { 2 - 7 } & Pb & Cd & Cu & Pb & Cd & Cu \\
\hline Średnia & 10,56 & 1,09 & 20,6 & 1,70 & 1,81 & 5,54 \\
\hline Max & 21,4 & 2,60 & 50,8 & 3,5 & 2,15 & 8,0 \\
\hline Min & 3,9 & 0,17 & 9,6 & 0,5 & 1,29 & 3,2 \\
\hline Mediana & 9,7 & 0,74 & 19,2 & 1,4 & 1,72 & 4,8 \\
\hline $\begin{array}{l}\text { Odchylenie } \\
\text { standardowe }\end{array}$ & 5,16 & 0,79 & 9,98 & 0,82 & 0,30 & 2,16 \\
\hline
\end{tabular}


kilkukrotnie podwyższone w stosunku do danych zawartych w Atlasie Geochemicznym na terenie Przemyśla $(\mathrm{Cd}<0,5 \mathrm{ppm})[8,9]$. Podobną sytuację zaobserwowano w przypadku koncentracji kadmu w korzeniach marchwi. Jego stężanie kształtuje się w przedziale 1,29 - 2,15 ppm s.m [11] (tab.1). Na podstawie analizy dopuszczalnych stężeń dla kadmu ujętych w rozporządzeniu KE [2011] oraz rozporządzeniu Ministra Środowiska [2003] można stwierdzić, że stężenie tego pierwiastka uzyskane w wyniku badań przeprowadzonych na terenie Przemyśla przekracza wartość dopuszczalną, wynoszącą $0,1 \mathrm{mg} \mathrm{kg}^{-1}$ świeżej masy [12,13].

Przeprowadzone badania mineralogiczne wykazały, że główną fazą mineralną badanych utworów jest kwarc. Obok kwarcu we wszystkich badanych próbkach stwierdzono minerały $\mathrm{z}$ grupy węglanów. Identyfikacja faz metodą dyfrakcji rentgenowskiej ujawnia, że w większości przypadków jest to kalcyt. Wykazano też obecność skaleni sodowo - wapniowych. Odmiany potasowe skaleni reprezentowane są przez ortoklaz i mikroklin. Obok wymienionych składników stwierdzono także obecność minerałów ilastych - kaolinitu, minerałów z grupy mik (illit, muskowit) oraz minerałów z grupy smektytu [9]. Powyższy skład fazowy jest typowy dla gleb macierzystych Przemyśla. Analiza zdjęć w SEM nie wykazała w badanych glebach obecności np. detrytycznych ziaren tlenków żelaza, sferul magnetycznych czy cząstek żelaza metalicznego, mogących świadczyć o zanieczyszczeniu gleb pyłami przemysłowymi. Po przeprowadzonej analizie składu chemicznego przy zastosowaniu metod mineralogicznych, nie można jednak wykluczyć, zanieczyszczeń pochodzących z pyłów elektrociepłowniczych, w których to składzie występują takie minerały, jak: kwarc, szkliwo krzemianowe i mullit [10].

Wizualizacja uzyskanych wyników przy zastosowaniu metod kartograficznych, pozwoliła zarejestrować na analizowanym terenie Przemyśla miejsca największej koncentracji metali ciężkich (Rys.3, Rys.4, Rys.5). Należą do nich obszary zlokalizowane wokół zakładów przemysłowych ZWP „Sanwil” oraz przy Elektrociepłowni “Zasanie” (Rys.3,4,5). Mapy korelacji pomiędzy środowiskiem glebowym a roślinnym potwierdzają wyniki badań geochemicznych. Miejsca największej koncentracji kadmu (Cd) pokrywają się z podwyższaną zwartością tego pierwiastka w roślinach (Rys.4).

Analizując stężenia pierwiastków na uzyskanych mapach korelacji zaobserwowano, iż najbardziej narażonym na wpływ zanieczyszczeń pochodzących z obiektów przemysłowych są obszary usytuowane w sąsiedztwie zakładu wyrobów powlekanych SANWIL. Podwyższony poziom zawartości wszystkich pierwiastków w tym rejonie, zarówno w glebie, jak i w roślinności, wskazuje na występowanie nienaturalnego źródła zanieczyszczeń identyfikowane na mapach w promieniu 1,5km od zakładu. Z przeprowadzonej analizy sytuacyjnej (Rys.1) i wysokościowej (Rys.2) wynika, iż zanieczyszczenia badanymi pierwiastkami nie mogły być rezultatem migracji spowodowanej np. dużą różnicą terenu bądź innymi ogniskami zanieczyszczeń. 


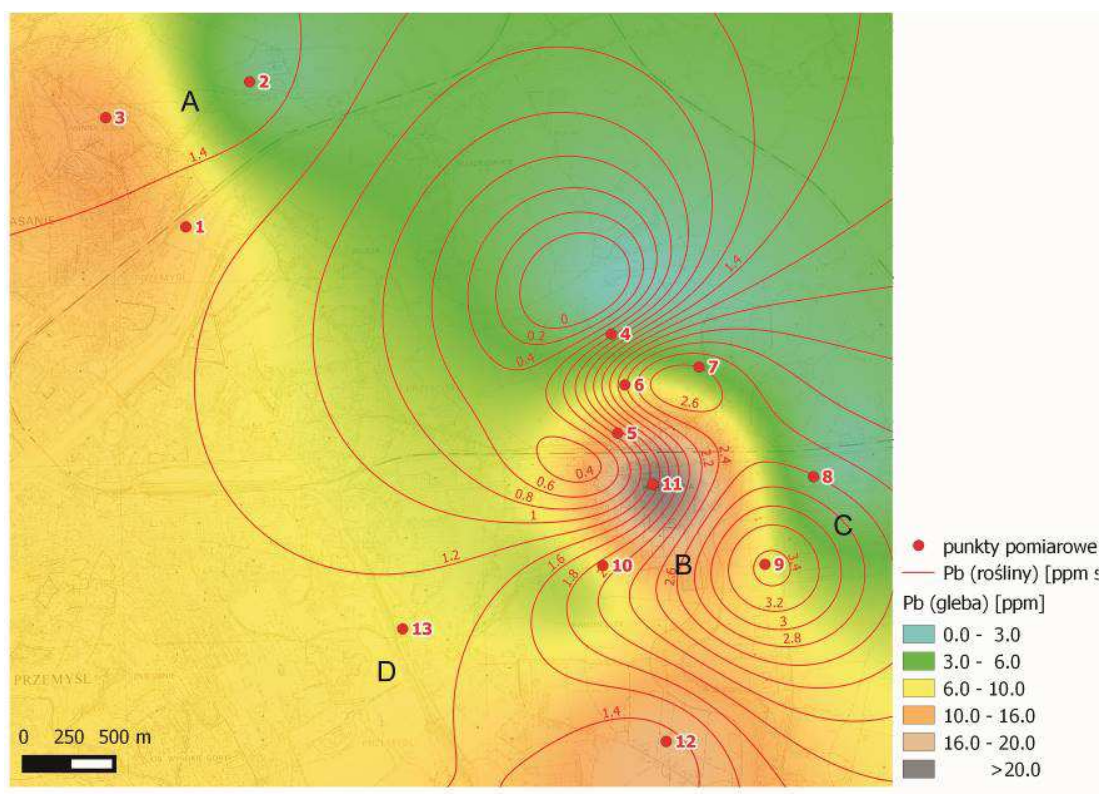

Rys.3. Mapa stężenia ołowiu $(\mathrm{Pb})$ w roślinach i glebach dla badanego obszaru.

Fig.3. Map showing the concentration of lead $(\mathrm{Pb})$ in plants and soil for the study area

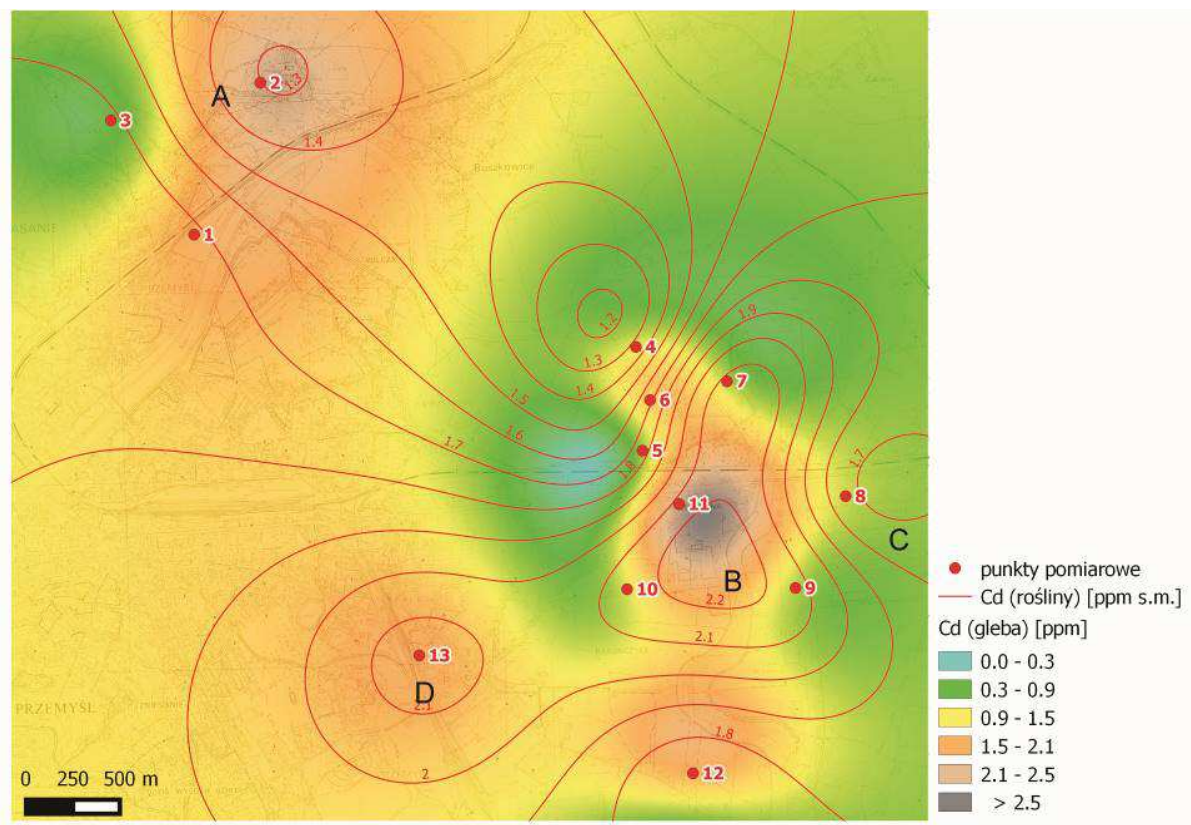

Rys.4. Mapa stężenia kadmu (Cd) w roślinach i glebie dla badanego obszaru .

Fig.4. Map showing the concentration of cadmium $(\mathrm{Cd})$ in plants and soil for the study area 


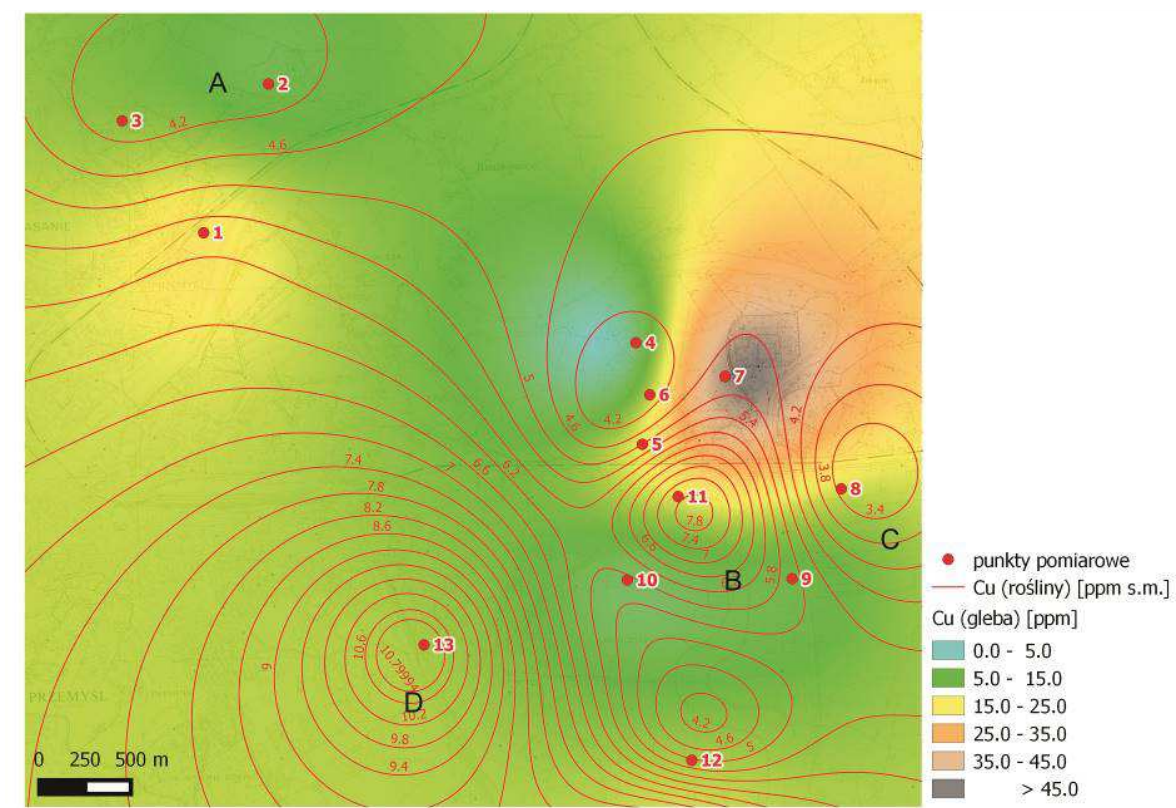

Rys.5. Mapa stężenia miedzi $(\mathrm{Cu})$ w roślinach i glebie dla badanego obszaru.

Fig. 5. Map showing the concentration of copper $(\mathrm{Cu})$ in plants and soil for the study area

\section{Podsumowanie}

Przeprowadzone badania geochemiczne oraz próba ich przestrzennej wizualizacji za pomocą map stężeń, pozwalają stwierdzić, że na analizowanym obszarze kadm wykazuje wartości podwyższone w stosunku do dopuszczalnego poziomu stężenia tego pierwiastka według rozporządzeń polskich i unijnych $[12,13]$. Na podstawie porównania uzyskanych w tym opracowaniu wyników z rezultatami badań z roku 1992 [6], kwalifikujących gleby w sąsiedztwie Elektrociepłowni „Zasanie” do III I IV klasy zanieczyszczeń kadmem, natomiast gleby w rejonie ZWP Sanwil do III klasy, można zaobserwować obniżenie poziomu zanieczyszczenia dla pierwszej z nich. Na mapach korelacji wyraźnie widać, iż w obecnej chwili głównym ogniskiem zanieczyszczeń jest obszar ZWP "Sanwil". W przypadku jakości gleb w rejonie Elektrociepłowni można zauważyć poprawę jakości środowiska glebowego, która prawdopodobnie jest wynikiem modernizacji zakładu (wyposażenie kotłów w system odpylania) przeprowadzonej w latach 2006-2007.

\section{Literatura}

[1] Graniczny M.: Kartowanie geologiczne z wykorzystaniem zdjęć satelitarnych Landsat. Biuletyn Państwowego Instytutu Geologicznego 2002, 420, s.27-50. 
[2] Graniczny M.: Remonte sensing: A perfect tool for solving geological and geoenvironmental cross-border issues. Prz.Geol.2004.52(8/2), s.731-737.

[3] Milton N.: Remote Sensing of Vegetation Responses to the Environment. U.S.Geol.Surv.Circ.1990.1033, s.51-51.

[4] Pasieczna A.: Mapy i atlasy geochemiczne-bogate źródło informacji o zanieczyszczeniu środowiska. REA - Centrum Doskonałości badań Środowiska Abiotycznego, 2004,nr 6, s.5-6,. PIG, 2015, http://www2.pgi.gov.pl/.

[5] Program Ochrony Środowiska dla Miasta Przemyśla na lata 2010-2013, z perspektywą do 2017r. Przyjęty Uchwałą Nr 231/2011 Rady Miejskiej w Przemyślu z dnia 29 września 2011r. i opublikowany w Dzienniku Urzędowym Województwa Podkarpackiego w dniu 24 listopada $2011 \mathrm{r}$.

[6] Raport o stanie środowiska w województwie przemyskim w latach 1995-1996. PIOŚ, WIOŚ w Przemyślu. Wyd. Biblioteka Monitoringu Środowiska. Przemyśl 1997.

[7] Rozporządzenie Ministra Środowiska z dnia 9 września 2002 r. w sprawie standardów jakości gleby oraz standardów jakości ziemi (Dziennik Ustaw - Dz. U. 2002, Nr 165 poz. 1359).

[8] Lis J., Pasieczna A.: Atlas geochemiczny Polski 1:2 500 000. Państwowy Instytut Geologiczny, Warszawa 1995.

[9] Pękala A. Ocena stanu geochemicznego gleb miasta Przemyśla. Górnictwo i Geologia. Tom 7, zeszyt 2, Gliwice 2012, 197-205.

[10] Manecki A., Klasyfikacja i skład mineralny pyłów atmosferycznych. Prace Mineralogiczne 57. PAN Kraków 1993.

[11] Pękala A.: Zawartość $\mathrm{Cd}, \mathrm{Pb}$ i $\mathrm{Cu}$ w korzeniu marchwi z ogródków działkowych Przemyśla. Geochemia i Geologia Środowiska terenów uprzemysłowionych. Wyd. P.A.NOVA. Gliwice 2014.

[12] Rozporządzenie Komisji UE NR 420/2011 z dnia 29 kwietnia 2011 r. zmieniające rozporządzenie (WE) nr 1881/2006 ustalające najwyższe dopuszczalne poziomy niektórych zanieczyszczeń w środkach spożywczych.

[13] Rozporządzenie Ministra Zdrowia z dnia 13 stycznia 2003 roku w sprawie maksymalnych poziomów zanieczyszczeń chemicznych i biologicznych (Dz.U. Nr 37, poz. 325).

\section{THE RESEARCH OF THE TRACE ELEMENTS CORRELATION IN SOIL-PLANT ENVIRONMENT USING GIS}

\section{S u m m a r y}

The aim of the present study is to identify anomalous geochemical concentrations in soils and root carrots originating from allotments of the Przemysl city. Using cartographic techniques there are made monitoring maps of environment pollution, including registrations of industrial plants emitting determined trace elements into the environment. These technologies have also helped to visualize the interaction between the natural system type soil / plant and preparation correlation maps between this system. In the implementation of the study there were used chemical testing to determine the concentration of cadmium, lead and copper in plants and soils. Mineralogical studies made it possible to determine the phase composition of the studied soils, designate also their acidity. There were used atomic absorption spectroscopy (AAS), X-ray diffraction, optical 
and scanning microscopy. All operations and activities associated with spatial analysis and mapping were made in opensource system QGIS / GRASS. The results of chemical testing for plant material and soils allow us to conclude that in all 14 measurement points there is exceeded the upper acceptable limit of Cd content given in Regulation 420/211 committee of the EU 2011. The contents of $\mathrm{Cu}$ and $\mathrm{Pb}$ in all samples does not exceed the permissible norms. The correlation maps between the soil environment and plant are confirmed by the results of geochemical research. Places highest concentration of cadmium correspond with the increased content of this element in plants.

Keywords: cartography, geochemistry, environmental monitoring, trace elements, cadmium, QGIS/GRASS

Przestano do redakcji: $30.10 .2015 \mathrm{r}$.

Przyjęto do druku: 1.03.2016 r.

DOI: $10.7862 / \mathrm{rb} .2016 .123$ 
